\title{
PENERAPAN MODEL PEMBELAJARAN PROBLEM SOLVING DILENGKAPI MEDIA LEMBAR KERJA PESERTA DIDIK (LKPD) SEBAGAI UPAYA MENINGKATKAN KEMAMPUAN BERPIKIR KRITIS SERTA PRESTASI BELAJAR SISWA PADA MATERI LARUTAN PENYANGGA KELAS XI IPA 3 SEMESTER II SMA NEGERI 2 SURAKARTA TAHUN PELAJARAN 2017/2018
}

\author{
Pingkan Puteri Intani, Bakti Mulyani”, dan Widiastuti Agustina E.S. \\ Program Studi Pendidikan Kimia, FKIP,Universitas Sebelas Maret, Surakarta, Indonesia \\ *Keperluan korespondensi, telp : 081227611216 , email: baktimulyani@staff.uns.ac.id
}

\begin{abstract}
ABSTRAK
Penelitian yang dilakukan memiliki tujuan meningkatkan kemampuan berpikir kritis serta prestasi belajar siswa melalui penerapan model pembelajaran Problem Solving dilengkapi Lembar Kerja Peserta Didik (LKPD) pada materi larutan penyangga kelas XI IPA 3 semester II SMA Negeri 2 Surakarta tahun pelajaran 2017/2018. Penelitian yang dilakukan adalah Penelitian Tindakan Kelas (PTK) dimana terdiri dari 2 siklus. Satu siklus terbagi 4 tahap yaitu perencanaan, pelaksanaan, observasi, dan refleksi. Pada penelitian yang bertindak sebagai subjek yaitu siswa kelas XI IPA 3 SMA Negeri 2 Surakarta tahun pelajaran 2017/2018. Teknik analisis yang digunakan adalah deskriptif kualitatif. Pengumpulan data dilaksanakan dengan teknik observasi, wawancara, angket, serta tes. Data bersumber dari guru dan siswa. Penelitian menunjukkan hasil penerapan model pembelajaran Problem Solving dilengkapi LKPD pada materi larutan penyangga dapat meningkatkan kemampuan berpikir kritis dan prestasi belajar siswa serta telah mencapai target baik aspek pengetahuan, sikap, dan keterampilan. Persentase ketercapaian kemampuan berpikir kritis siswa sebelum tindakan sebesar $32,35 \%$, pada siklus I mengalami peningkatan menjadi $41,18 \%$ dan mengalami peningkatan kembali menjadi $76,47 \%$ pada siklus II. Besarnya persentase ketercapaian prestasi belajar aspek pengetahuan siklus pertama yaitu $44,12 \%$ kemudian mengalami peningkatan menjadi $79,41 \%$ pada siklus kedua. Persentase ketercapaian aspek sikap pada siklus I adalah $91,17 \%$ dan mengalami peningkatan menjadi $100 \%$ pada siklus II. Sedangkan besarnya persentase aspek keterampilan siklus I yaitu $100 \%$.
\end{abstract}

Kata Kunci : Penelitian Tindakan Kelas, Problem Solving, Kemampuan Berpikir Kritis, Prestasi Belajar, Larutan Penyangga

\section{PENDAHULUAN}

Komponen utama yang berperan penting dalam kemajuan suatu bangsa adalah pendidikan. Hal ini disebabkan oleh pengaruh kualitas mutu pendidikan terhadap sumber daya manusia. Pada saat ini masalah pendidikan banyak disoroti oleh berbagai elemen. Upaya dalam meningkatkan prestasi belajar siswa dijadikan sebagai acuan perbaikan mutu pendidikan. Prestasi belajar terdiri dari tiga ranah, yaitu kognitif, sikap, dan psikomotor [1].
Berdasarkan riset keilmuan, pendidikan yang diterapkan di Indonesia menunjukkan hasil yang rendah jika dibandingkan dengan dengan negara berkembang yang lain, salah satunya ditunjukkan dari riset yang dilakukan oleh Programme for International Students Assesment (PISA) pada tahun 2012. Dimana pada riset tersebut menunjukkan hasil belum dimilikinya kemampuan literasi dasar seperti membaca, menulis serta sains oleh sebagian besar peserta didik Indonesia yang memiliki usia 15 tahun, sehingga pembaruan dan per- 
baikan mutu pendidikan di Indonesia sangat diperlukan. Pengintegrasian aspek pengetahuan, sikap, keterampilan yang didukung dengan penguasaan teknologi, informasi serta komunikasi merupakan kecakapan yang dibutuhkan pada pendidikan abad 21. Adanya inovasi model pembelajaran yang didasarkan pada kesesuaian materi pembelajaran serta karakteristik kompetensi dapat mengembangkan kecakapan pendidikan abad 21 . Kompetensi dapat dirumuskan dengan 4C, yaitu berpikir kritis dan pemecahan masalah (Critical Thinking and Problem Solving Skill), kecakapan berkomunikasi (Communication Skills), kreativitas dan inovasi (Creativity and Innovation), serta kolaborasi (Collaboration). Keterampilan berpikir tingkat tinggi atau biasa yang disebut Higher Order Thinking Skills (HOTS) adalah kecakapan yang diperlukan oleh peserta didik dalam pendidikan abad 21 [2].

Kimia merupakan ilmu yang di dalamnya mempelajari senyawa yang memiliki sifat tertentu, serta hal-hal yang terjadi pada saat pembentukannya. IImu kimia berisi pengetahuan secara teori dan praktik. Selain itu, pengetahuan berisi keterkaitan antara cara untuk mengetahui sesuatu yang ada di alam dengan runtut, pada akhirnya ilmu kimia diharapkan bukan hanya sekumpulan konsep, fakta, dan prinsip namun menjadi sebuah pembelajaran yang didalamnya memiliki proses penemuan sehingga mampu memberikan pengalaman yang bermakna [3].

Berdasarkan hasil observasi pada saat guru menyampaikan materi diperoleh temuan bahwa guru masih menggunakan metode ceramah. Peserta didik cenderung mengalami kesulitan dalam menghubungkan permasalahan dalam peristiwa sehari-hari dengan teori yang diperoleh selama belajar kimia. Guru menganggap bahwa metode ceramah merupakan cara praktis yang dapat dilakukan sebab tidak membutuhkan waktu yang banyak. Hal tersebut akan mengakibatkan komunikasi selama kegiatan belajar mengajar berjalan hanya searah, sedangkan peserta didik menjadi kritis ketika dalam kegiatan belajar-mengajar terjadi komunikasi multi arah.

Menurut data ketuntasan Ulangan Tengah Semester I tahun 2017/2018, diperoleh informasi bahwa kelas XI IPA 3 memiliki nilai paling rendah diantara ketiga kelas lainnya, data disajikan dalam Tabel 1.

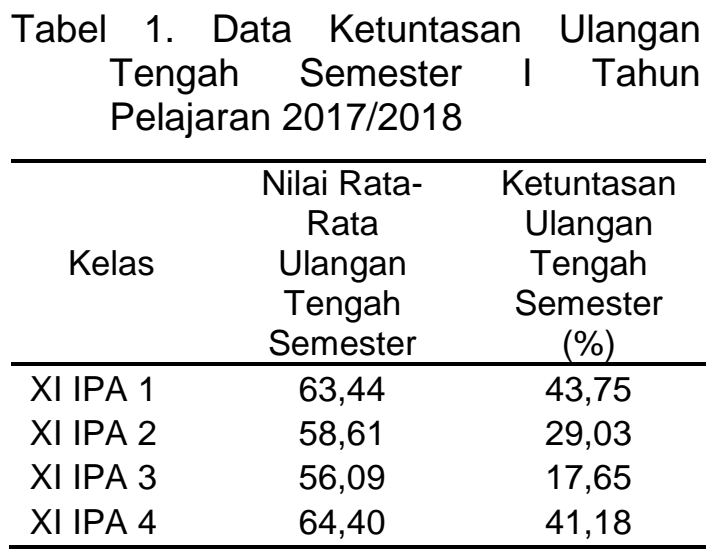

Tabel 1 menunjukkan bahwa data bahwa kelas XI IPA 3 memiliki persen rata-rata ketuntasan ulangan tengah semester yang paling rendah diantara ketiga kelas lainnya. Berdasarkan daftar nilai kimia materi asam basa kelas XI IPA 3 tahun ajaran 2017/2018 didapatkan data bahwa nilai rata-rata pada materi tersebut sebesar 57,20 dengan sebanyak 10 siswa atau $29,41 \%$ yang tuntas. Dari data ini dapat disimpulkan bahwa sebagian besar siswa kelas XI IPA 3 belum memahami konsep asam basa secara baik. Hal ini akan berdampak pada materi selanjutnya yaitu larutan penyangga.

Permasalahan yang terjadi pada materi larutan penyangga adalah peserta didik kurang siap dalam menerima materi pelajaran, kurang memahami konsepkonsep penting yang menjadi konsep prasyarat larutan penyangga yaitu konsep mol, stoikiometri, serta larutan asam dan basa. Selain itu, penanaman konsep materi larutan penyangga yang kurang mendalam. Larutan penyangga merupakan salah satu pokok materi yang sukar, sebab mempunyai karakteristik berupa pemahaman konsep dan kemampuan matematis. Berdasarkan hal tersebut, maka siswa dituntut untuk berpikir secara kritis, analisis dan kreatif serta pemahaman konsep yang tepat 
dalam memecahkan soal dengan langkah yang tepat.

Pemerintah selalu berupaya memberi penekanan proses sains pada pembelajaran untuk menekankan pembelajaran, salah satunya yaitu diberlakukannya kurikulum 2013. Terciptanya insan produktif, kreatif, serta inovatif yang terintegrasi dengan pengetahuan, sikap, serta keterampilan merupakan tujuan dari kurikulum 2013 [4]. Panduan model pembelajaran yang sesuai dengan kurikulum 2013 diatur dalam Peraturan Menteri Pendidikan dan Kebudayaan Nomor 65 Tahun 2013 yang mengatur tentang Standar Proses. Dimana pada kurikulum 2013 dianjurkan untuk menerapkan model pembelajaran penemuan (discovery), model pembelajaran inkuiri, model pembelajaran berbasis proyek, model pembelajaran pemecahan masalah, serta model pembelajaran berbasis masalah. Akan tetapi, pada pelaksanaannya SMA Negeri 2 Surakarta belum sepenuhnya menerapkan model pembelajaran yang sesuai dengan pendekatan scientific.

Model pembelajaran Problem Solving adalah salah satu model yang termasuk dalam pendekatan scientific. Problem Solving merupakan model pembelajaran yang pada pelaksanaannya memberikan sajian materi pada siswa terhadap suatu permasalahan yang hendak dipecahkan. Problem Solving terdiri atas 5 tahap yaitu mendefinisikan masalah, mencari data atau keterangan, menetapkan jawaban sementara, menguji kebenaran jawaban, dan menarik kesimpulan [5].

Selain prestasi belajar hal mendasar dari kriteria ilmu kimia adalah menekankan pada proses. Interaksi serta kemampuan berpikir lebih ditekankan pada penilaian proses. Disamping itu, salah satu kompetensi utama yang dapat diukur dalam kecakapan abad 21 yang dirumuskan dalam 4C adalah berpikir kritis (critical thinking). Kemampuan berpikir kritis dapat diartikan dengan suatu potensi yang dimiliki oleh setiap individu dalam hal menguraikan secara sistematis argumennya dan menyajikan interpretasi yang didasarkan pada pemikiran yang realistis dan logis [6]. Berpikir kritis juga dapat diartikan sebagai pikiran yang memiliki sifat jelas, berdasarkan fakta, serta terbuka. [7]. Sebagian besar siswa memiliki kemampuan hafalan yang tinggi, akan tetapi hal yang telah dipelajari kurang dimaknai [8].

Pemanfaatan media selama proses belajar dapat membantu meningkatkan hasil belajar yang dicapai siswa. Berdasarkan salah satu penelitian, meningkatnya pemahaman konsep ilmu pengetahuan dan prestasi belajar siswa merupakan pengaruh dari peran penggunaan media dalam pembelajaran [9]. Selama ini kegiatan pembelajaran kimia di SMA Negeri 2 Surakarta khususnya kelas XI kurang menarik, sehingga menyebabkan siswa menjadi pasif. Oleh karena itu, dibutuhkan media yang mampu memberi petunjuk dan membatasi permasalahan yang akan dipecahkan oleh siswa serta mengoptimalkan kemampuan berpikir siswa yaitu dengan menggunakan media Lembar Kerja Peserta Didik (LKPD). LKPD merupakan lembaran-lembaran yang berisi tugas baik teori maupun praktik yang dikerjakan oleh peserta didik [10].

Berdasarkan berbagai permasalahan yang telah di uraikan di atas, prestasi belajar dan kemampuan berpikir kritis siswa kelas XI IPA 3 SMA Negeri 2 Surakarta dapat ditingkatkan dengan upaya menerapkan model pembelajaran Problem Solving pada materi larutan penyangga dilengkapi dengan lembar kerja peserta didik.

\section{METODE PENELITIAN}

Penelitian dilaksanakan di SMA Negeri 2 Surakarta yang bertempat di Jalan Mongonsidi nomor 40 Surakarta. Jenis penelitian yang dilakukan merupakan Penelitian Tindakan Kelas (PTK) dimana didalamnya terdapat 2 siklus. Secara umum, satu siklus memiliki empat tahap yaitu perencanaan, pelaksanaan, observasi, dan refleksi [11]. Pada penelitian ini yang menjadi subjek siswa kelas XI IPA 3 SMA Negeri 2 Surakarta tahun pelajaran 2017/2018. Guru dan siswa merupakan sumber data 
pada penelitian ini. Data dikumpulkan melalui tes serta non tes yang terdiri dari hasil observasi, wawancara, angket, dan tes.

Pelaksanaan Penelitian Tindakan Kelas (PTK) analisis data dilaksanakan dari awal hingga didapatkannya data terakhir. Hasil data yang diperoleh dari penelitian kemudian dianalisis dan diolah secara deskriptif kualitatif. Model analisis Miles dan Huberman merupakan teknik analisis kualitatif yang digunakan pada penelitian ini, dimana dilakukan dengan berkesinambungan yaitu proses reduksi data, penyajian data, penarikan kesimpulan serta verifikasi [12]. Validitas data pada penelitian ini diperiksa dengan teknik triangulasi. Triangulasi merupakan suatu teknik untuk memeriksa keabsahan data dengan menggunakan faktor lain yang berada di luar data itu yang berperan sebagai pembanding data tersebut [13].

\section{HASIL DAN PEMBAHASAN}

Berdasarkan nilai Ulangan Tengah Semester Ganjil, nilai rata-rata paling rendah diantara ketiga kelas yang lainya dimiliki oleh kelas XI IPA 3. Selain itu nilai rata-rata ulangan harian asam basa kelas XI IPA 3 sebesar 58,09 dengan persentase siswa yang tuntas $41,18 \%$, sehingga kelas XI IPA 3 diperlukan perbaikan melalui penelitian tindakan kelas. Selain prestasi belajar, kemampuan berpikir kritis siswa kelas XI IPA 3 juga perlu ditingkatkan.

Penelitian ini merupakan penelitian tindakan kelas dengan menerapkan model pembelajaran Problem Solving berbantuan LKPD pada materi larutan penyangga. Pembelajaran ini merupakan pembelajaran yang berpusat pada siswa dimana siswa dituntun mengembangkan pengetahuannya sendiri dan guru bertindak sebagai fasilitator. Problem Solving diharapkan dapat ditetapkan untuk materi pokok larutan penyangga karena dapat membentuk siswa mengembangkan kemampuan berpikir, pemecahan masalah dan keterampilan berpikir. Model pembelajaran tersebut juga dapat melatih kemandirian dalam menyelesaikan masalah dan merumus- kan kesimpulan. Melalui model Problem Solving ini kemampuan berpikir kritis siswa akan diasah dengan cara memecahkan masalah yang diberikan sehingga kemampuan berpikir kritisnya akan meningkat. Saat kemampuan berpikir kritisnya meningkat diharapkan pula prestasi belajar siswa pada materi larutan penyangga juga meningkat.

\section{Siklus I}

\section{a. Perencanaan Tindakan}

Tahap perencanaan tindakan siklus I dimulai dengan mencari silabus Kurikulum 2013 pelajaran kimia materi pokok larutan penyangga di internet dengan sumber yang valid, silabus tersebut disusun oleh pemerintah. Silabus yang diperoleh kemudian dikembangkan dengan menggunakan model pembelajaran Problem Solving berdasarkan diskusi dan persetujuan oleh guru yang bersangkutan. Berdasarkan silabus tersebut, peneliti menyusun instrumen-instrumen pembelajaran yang diperlukan. Instrumen pembelajaran yang pertama yaitu Rencana Pelaksanaan Pembelajaran (RPP). Dalam silabus alokasi waktu yang disediakan untuk materi larutan penyangga adalah 12 jam pelajaran (JP). Berdasarkan waktu tersebut, peneliti membuat rencana pembelajaran untuk siklus I dengan rincian $6 \mathrm{JP}$ untuk penyampaian materi larutan penyangga dan 2 JP untuk evaluasi kegiatan pembelajaran siklus I. Penyusunan instrumen selanjutnya adalah alat evaluasi pembelajaran yang mencakup aspek pengetahuan, sikap, keterampilan, kemampuan berpikir kritis dan LKPD.

\section{b. Pelaksanaan Tindakan}

Sub pokok bahasan yang dipelajari pada siklus I diantaranya mendeskripsikan sifat larutan penyangga beserta pembuatannya, menganalisis terbentuknya larutan penyangga dengan $\mathrm{pH}$ tertentu, menghitung nilai $\mathrm{pH}$ larutan penyangga, serta prinsip kerja larutan peyangga dan fungsi larutan penyangga dalam kehidupan sehari-hari.

Kegiatan pembelajaran diawali dengan memberi apersepsi yang masih 
berkaitan dengan kehidupan sehari-hari. Selanjutnya siswa menyimak tujuan pembelajaran, kemudian menyimak penjelasan singkat dari guru. Tahap selanjutnya, siswa diminta mencari informasi yang luas dan dalam saat menjawab soal yang terdapat pada LKPD dengan menggunakan berbagai sumber, baik dari buku pegangan maupun internet yang dikerjakan bersama kelompok masing-masing yang telah dibagi oleh guru secara heterogen. Pada tahap ini, siswa diberikan kesempatan bertanya pada guru jika mengalami kesulitan dalam mengerjakan soal dalam LKPD. Selain itu, siswa juga diberi kesempatan untuk berpikir dan mengidentifikasi masalah yang diberikan.

Setelah proses diskusi selesai, siswa diberi kesempatan untuk menyajikan hasil diskusi kelompok di depan kelas dan kelompok lain diperbolehkan untuk memberi tanggapannya. Diskusi ditutup dengan guru menyamakan persepsi dan memberikan penguatan sehingga siswa menjadi lebih paham. Guru bersama-sama dengan siswa menyimpulkan hasil pembelajaran.

Siklus I diakhiri dengan dilakukannya tes pengetahuan agar dapat mengetahui tingkat pemahaman siswa terhadap bab larutan penyangga berupa 25 butir soal obyektif, tes kemampuan berpikir kritis berupa 20 butir soal obyektif, serta angket penilaian sikap berjumlah 40 butir soal.

\section{c. Observasi}

Observasi dilakukan oleh peneliti dibantu beberapa observer untuk menilai aspek sikap dan aspek keterampilan siswa pada saat kegiatan belajar mengajar siklus I sedang berlangsung.

\section{d. Hasil Tindakan Siklus I}

Berdasarkan hasil analisis tes kemampuan berpikir kritis didapatkan persentase predikat tinggi sebesar $41,18 \%$, aspek pengetahuan pada siklus I menunjukkan terdapat 15 siswa $(44,12 \%)$ sudah melampaui kriteria ketuntasan minimal (KKM) dan 19 siswa $(55,88 \%)$ belum melampaui kriteria ketuntasan minimal (KKM). Dari hasil tersebut dapat disimpulkan bahwa target kemampuan berpikir kritis dan aspek pengetahuan belum mencapai target yang ditentukan yaitu 60\%. Dari hasil penilaian aspek sikap pada siklus I, siswa yang mempunyai kategori sikap sangat baik sebanyak $32,35 \%$, siswa berkategori baik sebanyak $58,82 \%$, dan siswa berkategori cukup baik sebanyak $8,82 \%$. Untuk hasil penilaian aspek keterampilan adalah sebesar $100 \%$ mendapat predikat minimal B (Baik). Berdasarkan target yang telah ditetapkankan, sehingga hasil persentase ketercapaian siklus I dapat dilihat pada Tabel 2.

Tabel 2. Ketercapaian Target Keberhasilan Siklus I

\begin{tabular}{|c|c|c|c|}
\hline Aspek & $\begin{array}{c}\text { Target } \\
(\%)\end{array}$ & $\begin{array}{l}\text { Ketercapaian } \\
(\%)\end{array}$ & Kriteria \\
\hline $\begin{array}{l}\text { Kemampuan } \\
\text { Berpikir Kritis }\end{array}$ & 60 & 41,18 & $\begin{array}{l}\text { Tidak } \\
\text { Tercapa }\end{array}$ \\
\hline Pengetahuan & 60 & 44,12 & $\begin{array}{l}\text { Tidak } \\
\text { Tercapa }\end{array}$ \\
\hline $\begin{array}{l}\text { Sikap } \\
\text { Keterampilan }\end{array}$ & $\begin{array}{l}75 \\
70 \\
\end{array}$ & $\begin{array}{r}91,17 \\
100,00 \\
\end{array}$ & $\begin{array}{l}\text { Tercapa } \\
\text { Tercapa }\end{array}$ \\
\hline
\end{tabular}

\section{e. Refleksi}

Berdasarkan hasil penelitian yang diperoleh pada pembelajaran siklus I, terdapat aspek pengetahuan serta aspek kemampuan berpikir kritis yang belum mencapai target ketercapaian. Hal tersebut disebabkan oleh kurangnya kesadaran siswa akan pentingnya kerjasama dalam menyelesaikan permasalahan, selain itu siswa juga masih menyepelekan pembelajaran dengan model Problem Solving serta belum mengerti kontribusinya dalam kelompok. $\mathrm{Hal}$ ini membuat nilai aspek pengetahuan serta kemampuan berpikir kritis siswa belum mencapai target. Maka dari itu dilaksanakan tindakan selanjutnya yaitu perlu direncanakan adanya pembelajaran siklus II, dari siklus II ini diharapkan kemampuan berpikir kritis dan hasil belajar siswa pada materi larutan penyangga dapat mencapai target yang ditentukan. Untuk aspek keterampilan tidak dilaksanakan penilaian pada siklus kedua sebab saat siklus pertama sudah mencapai $100 \%$. 


\section{Siklus II}

\section{a. Perencanaan Tindakan}

Hasil refleksi pada siklus । menunjukkan perlunya dilakukan tindak lanjut untuk memperbaiki serta menyempurnakan pada hambatan-hambatan yang terjadi pada siklus I, sehingga dirancang rencana siklus II. Tindakan tersebut antara lain mendiskusikan indikator yang belum tuntas pada evaluasi siklus I. Diharapkan guru mampu menumbuhkan kemampuan berpikir kritis siswa dengan mengajak siswa untuk menanyakan bagian materi atau kesulitan dalam memecahkan masalah pada materi larutan penyangga. Oleh karena itu, hasilnya mencapai target dan lebih baik pada siklus II.

\section{b. Pelaksanaan Tindakan}

Pelaksanaan saat siklus II, pembahasan materi difokuskan pada dua indikator yaitu menghitung nilai $\mathrm{pH}$ dan prinsip kerja larutan penyangga. Hal tersebut dilakukan dengan cara mendalami pemecahan masalah pada soal-soal yang ada pada LKPD. Siswa diharapkan mampu mengevaluasi bagian mana yang dirasa masih sulit, hal ini dibuktikan dengan adanya beberapa siswa yang menanyakan langkahlangkah tertentu pada saat pengerjaan soal. Misalnya dalam menentukan volume dari masing-masing larutan yang harus dicampurkan agar terbentuk larutan penyangga, siswa masih merasa kesulitan dalam membuat permisalan. Pertanyaan siswa tersebut kemudian dibantu oleh guru dengan cara memberi bimbingan dan penekanan pada siswa untuk memecahkan masalah secara analisis tentang bagaimana membuat suatu pemisalan volume total agar bisa didapatkan volume masing-masing campuran.

Siklus II diakhiri dengan dilakukannya tes pengetahuan untuk dapat mengetahui tingkat kepahaman siswa terhadap materi larutan penyangga berupa 10 butir soal obyektif, tes kemampuan berpikir kritis berupa 20 butir soal pilihan ganda, serta angket penilaian sikap berjumlah 40 butir soal.

\section{c. Observasi}

Tahap observasi dilakukan oleh peneliti dan beberapa observer untuk menilai aspek sikap siswa pada saat kegiatan belajar mengajar siklus II sedang berlangsung.

\section{d. Hasil Tindakan Siklus II}

Berdasarkan analisis hasil tes yang dilaksanakan pada pembelajaran siklus II, didapatkan sebanyak 27 siswa $(79,41 \%)$ sudah melampaui kriteria ketuntasan minimal (KKM) dan 7 siswa $(20,59 \%)$ belum melampaui kriteria ketuntasan minimal (KKM). Dari hasil tersebut, dapat disimpulkan bahwa aspek pengetahuan telah mencapai target ada siklus II yaitu sebesar $60 \%$. Untuk penilaian kemampuan berpikir kritis didapatkan hasil sebesar 76,47\% siswa mempunyai kemampuan berpikir kritis yang tinggi. Dari penilaian aspek sikap siswa pada siklus II didapatkan persentase ketercapaian sebesar $100 \%$.

Ketercapaian keberhasilan kemampuan berpikir kritis siswa, aspek pengetahuan siswa pada materi larutan penyangga dan sikap siswa dalam siklus II dapat dilihat pada Tabel 3 .

Tabel 3. Ketercapaian Target Keberhasilan Siklus II

\begin{tabular}{lccc}
\hline \multicolumn{1}{c}{ Aspek } & $\begin{array}{c}\text { Target } \\
(\%)\end{array}$ & $\begin{array}{c}\text { Ketercapaian } \\
(\%)\end{array}$ & Kriteria \\
\hline $\begin{array}{l}\text { Kemampuan } \\
\text { Berpikir } \\
\text { Kritis }\end{array}$ & 60 & 76,47 & Tercapai \\
$\begin{array}{l}\text { Pengetahuan } \\
\text { Sikap }\end{array}$ & 60 & 79,41 & Tercapai \\
\hline
\end{tabular}

Berdasarkan hasil penelitian pada siklus II dapat dilihat bahwa kemampuan berpikir kritis dan aspek pengetahuan sudah mencapai target yang telah ditetapkan. Sehingga dapat disimpulkan bahwa pembelajaran pada materi larutan penyangga dengan menerapkan model pembelajaran Problem Solving berbantuan LKPD telah berhasil karena sudah melampaui target yang telah ditetapkan. Penelitian diakhiri pada siklus II karena kualitas proses yaitu kemampuan 
berpikir kritis serta prestasi belajar siswa yang mencakup aspek pengetahuan, sikap serta keterampilan sudah melampaui target yang telah ditetapkan.

Hasil penelitian ini sesuai dengan penelitian sebelumnya yang dilakukan yang menunjukkan bahwa model Problem Solving dapat meningkatkan prestasi belajar, baik aspek pengetahuan dan sikap serta memberikan respon positif pada siswa kelas XI IPA [14]. Hasil ini juga sesuai dengan penelitian lainnya yang menyimpulkan bahwa meningkatnya prestasi belajar siswa disebabkan oleh penggunaan model pembelajaran Problem Solving [15].

\section{Perbandingan Hasil Tindakan Antar- siklus}

Setiap pelaksanaan siklus, dilakukan penilaian terhadap aspek pengetahuan dan kemampuan berpikir kritis di akhir siklus, observasi aspek sikap di setiap proses pembelajaran berlangsung dan angket penilaian diri pada akhir siklus, dan aspek keterampilan pada pertemuan pertama sampai ketiga.

Berdasarkan penelitian yang telah dilakukan, tes kemampuan berpikir kritis siklus I siswa dengan kriteria kemampuan berpikir kritis tinggi sebanyak 14 siswa $(41,18 \%)$, siswa yang memiliki kriteria kemampuan berpikir kritis sedang sebanyak 18 siswa (52,94\%), dan siswa yang memiliki kriteria kemampuan berpikir kritis rendah sebanyak 2 siswa $(5,88 \%)$. Hasil tes kemampuan berpikir kritis siklus II menunjukkan bahwa siswa yang mempunyai kemampuan berpikir kritis tinggi sebanyak 25 siswa $(74,47 \%)$, dan siswa yang mempunyai kemampuan berpikir kritis sedang sebanyak 8 $(23,53 \%)$. Perbandingan kemampuan berpikir kritis siswa pada siklus I dan siklus II dapat dilihat pada Gambar 1. Berdasarkan hasil tes kemampuan berpikir kritis siswa pada siklus II diketahui bahwa terdapat peningkatan kemampuan berpikir kritis siswa dibandingkan dengan siklus I.

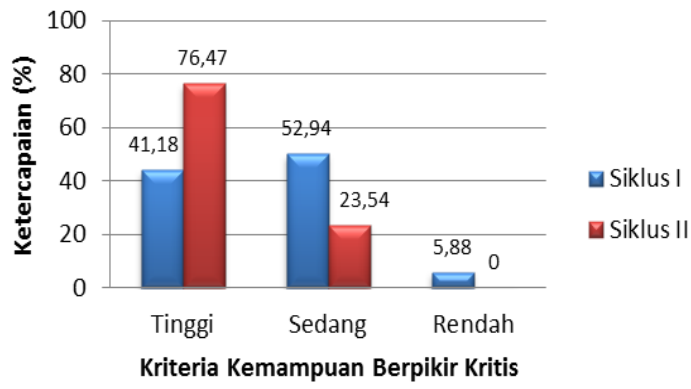

Gambar 1. Diagram Persentase Ketercapaian Kriteria Kemampuan Berpikir Kritis Siswa

Perbandingan hasil tes aspek pengetahuan siswa siklus I dan siklus II ditunjukkan pada Gambar 2.

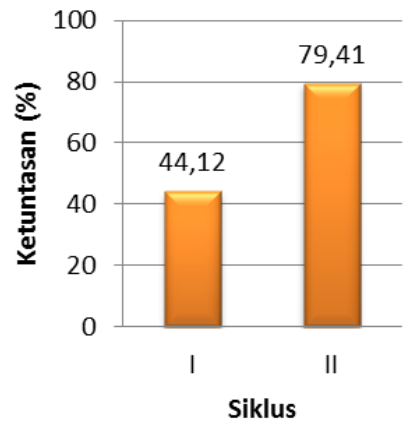

Gambar 2. Peningkatan Ketercapaian Ketuntasan Aspek Pengetahuan Siklus I dan Siklus II

Tampak pada Gambar 2, diketahui bahwa aspek pengetahuan siswa mengalami peningkatan, dimana pada siklus I capaian persentase sebesar $44,12 \%$ menjadi $79,41 \%$ pada siklus II.

Penilaian aspek sikap digunakan teknik triangulasi yang terdiri dari observasi, angket dan wawancara. Perbandingan ketercapaian target setiap siklus ditunjukkan pada Gambar 3.

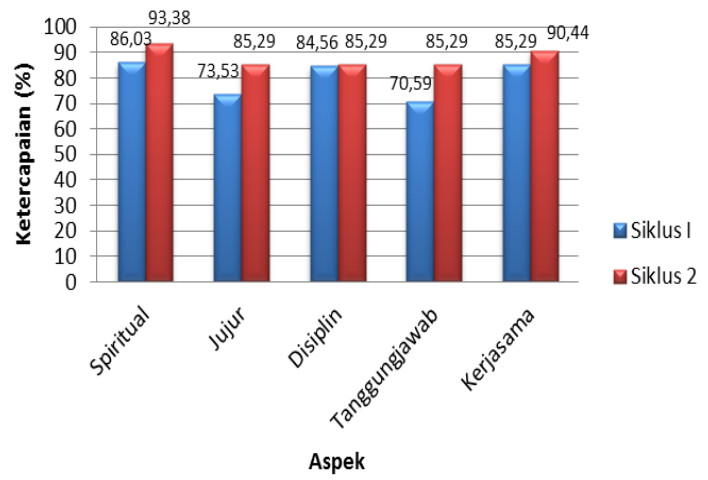

Gambar 3. Diagram Peningkatan Aspek Sikap Siklus I dan II 
Berdasarkan Gambar 3, dapat diketahui bahwa setiap aspek sikap siswa pada siklus II mengalami peningkatan dan secara keseluruhan target tercapai. Selain itu, dapat pula dilihat bahwa terjadi peningkatan persentase aspek sikap pada kategori sangat baik, sedangkan persentase siswa dengan kategori baik dan cukup mengalami penurunan. Pada siklus I dan II tidak terdapat siswa dalam kategori kurang baik. Pada siklus II sudah tidak ada siswa dengan kategori sikap cukup, peningkatan kategori penilaian aspek sikap siklus I dan siklus II dapat dilihat pada Gambar 4.

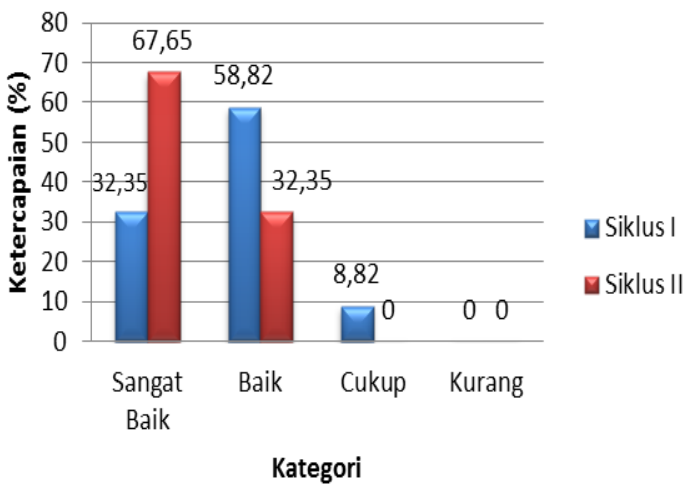

Gambar 4. Diagram Peningkatan Kategori Penilaian Aspek Siklus I dan II

Penilaian pada aspek keterampilan dilakukan dengan observasi saat kegiatan presentasi siswa berlangsung. Hasil penilaian aspek keterampilan pada siklus I didapatkan capaian persentase predikat minimal baik sebesar $100 \%$, sehingga untuk aspek keterampilan tidak diperbaiki kembali pada siklus II.

Peningkatan kemampuan berpikir kritis dan prestasi belajar pada penelitian ini ditunjang dengan penggunaan media berupa LKPD. Peran yang dimiliki LKPD cukup besar dalam penerapan model pembelajaran Problem Solving yaitu sebagai media untuk mempermudah tercapainya tujuan pembelajaran, sebab LKPD merupakan panduan belajar yang dapat menstimulasi siswa untuk berpikir kritis melalui soal-soal diskusi dan soal latihan yang ada di dalam LKPD tersebut. Dimana soal-soal tersebut terdiri dari berbagai variasi jenjang, mulai dari jenjang aplikasi (C3) hingga HOTS.
Selain soal-soal juga terdapat prosedur kerja demonstrasi yang dapat dipraktikkan oleh siswa saat pembelajaran.

\section{KESIMPULAN}

telah dilaksanakan, maka dapat disimpulkan bahwa penerapan model pembelajaran Problem Solving dilengkapi LKPD dapat meningkatkan kemampuan berpikir kritis dan prestasi belajar siswa kelas XI IPA 3 SMA Negeri 2 Surakarta tahun pelajaran 2017/2018 pada materi larutan penyangga serta telah mencapai target yang telah ditentukan. Sebelum penelitian tindakan kelas dilakukan persentase kemampuan berpikir kritis siswa dengan kategori tinggi sebesar $32,35 \%$, pada siklus I mengalami peningkatan menjadi $41,18 \%$, sedangkan pada siklus II siswa dengan kategori kemampuan berpikir kritis tinggi juga meningkat menjadi $76,47 \%$. Persentase capaian siswa tuntas aspek pengetahuan pada siklus I sebesar $44,12 \%$ mengalami peningkatan di siklus II menjadi $79,41 \%$, hasil ini telah mencapai target. Persentase aspek sikap telah mencapai target dengan kategori minimal baik pada siklus I yaitu $91,17 \%$ mengalami peningkatan di siklus II yaitu sebesar $100 \%$. Persentase aspek keterampilan telah mencapai target dengan kategori minimal baik pada siklus I sebesar $100 \%$.

\section{UCAPAN TERIMA KASIH}

Peneliti mengucapkan terima kasih kepada Bapak Drs. Sutikno, M,M. selaku Kepala Sekolah yang telah memberikan izin penelitian di SMA Negeri 2 Surakarta, serta Ibu Nanik Mitayani, S.Pd., M.Pd. selaku guru pengampu kimia yang telah mengijinkan peneliti melakukan penelitian di kelas XI IPA SMA Negeri 2 Surakarta.

\section{DAFTAR RUJUKAN}

[1] Haryati, M., 2007, Model \& Teknik Penilaian Pada Tingkat Satuan Pendidikan, Jakarta, Gaung Persada Press. 
[2] Kementerian Pendidikan dan Kebudayaan, 2017, Panduan Implementasi Kecakapan Abad 21 Kurikulum 2013 di Sekolah Menengah Atas.

[3] Hardini, I. P., 2012, Strategi Pembelajaran Terpadu, Yogyakarta, Familia.

[4] Mulyasa, E., 2014, Pengembangan Implementasi Kurikulum 2013, Bandung, Remaja Rosdakarya.

[5] Trianto, 2010, Mendesain Model Pembelajaran Inovatif-Progresif, Jakarta, Kencana Prenada Media.

[6] Yamin, M., 2008, Paradigma Pendidikan Kontruktivistik, Jakarta, Gaung Persada Press.

[7] Harsanto, R, 2005, Melatih Anak Berpikir Analistis, Kritis, dan Kreatif, Jakarta, Gramedia Widiasarana Indonesia.

[8] Nugraheni, D., Mulyani, S., dan Ariani, Sri R.D., 2013, Jurnal Pendidikan Kimia, 2(3), 34-41.
[9] Sahebzadeh, B., Kikha, A., Afshari Z., dan Kharadmand, Z., 2013, IJONTE, 4(8), 75-88.

[10] Katriani, L., 2014, Pengembangan Lembar Kerja Peserta Didik, Yogyakarta, Universitas Negeri Yogyakarta.

[11] Arikunto, S,. 2008, Penelitian Tindakan Kelas, Jakarta, Bumi Aksara.

[12] Sugiyono, 2013, Metode Penelitian Kuantitatif, Kualitatif, dan $R n D$, Bandung, Alfabeta.

[13] Moleong, L., 2009, Metodologi Penelitian Kualitatif, Bandung, Refika Adiatma.

[14] Sariwati, L. N., Utami, B., dan Masykuri M., 2015, Jurnal Pendidikan Kimia, 4(4), 123-131.

[15] Öner, F., Celik, A.Y., dan Sagir, U.S., 2009, Procedia, 1,26782684.https://doi.org/10.1016/j.sbsp ro.2009 .01.473 